\title{
Repudium i jego skutki prawne w Nowelach Justyniana
}

Nawet pobieżne zapoznanie się z nowelami Justyniana pozwala postawić hipotezę, że ich autor, w odróżnieniu od kodyfikacji, znacznie ograniczył w nich legalne możliwości jednostronnego oddalenia małżonka ${ }^{1}$. Regulacje w tym zakresie zawierają Nov. 22 z 536 roku, Nov. 74 z 538 roku, Nov. 117 z 542 roku, Nov. 123 z 546 roku, Nov. 127 z 548 roku oraz Nov. 134 z 556 roku.

Przedmiotem niniejszego artykułu jest analiza dyspozycji przepisów zawartych w poszczególnych nowelach z uwzględnieniem systematyki repudiów przyjętej przez Justyniana. W kolejności zostaną wyjaśnione przepisy regulujące kwestię repudium propter iustam causam, repudium bona gratia oraz repudium sine iusta causa oraz omówione skutki prawne, jakie wynikały z ich dokonania. Artykuł powinien przynieść odpowiedź na pytanie, w jakim stopniu Justynian ograniczył starożytną zasadę wolności w sprawach małżeńskich².

I. Wbrew idei chrześcijańskiej o nierozerwalności małżeństwa ${ }^{3}$ Justynian podkreślał, że małżeństwo, analogicznie do innych więzi ludzkich, jest rozerwalne. Ku tej idei skłonił się w sposób jednoznaczny w Noweli 22 z 535 roku. Przede wszystkim powtórzył w niej słuszne powody repudium wymienione w C. $5,17,8$ i w C. $5,17,11,2^{4}$.

W Nov. 22,15,1 zgromadził zawinione przyczyny, których udowodnienie upoważniało kobietę do dokonania repudium, gdzie obok wymienionych uprzednio w konstytucji Teodozjusza II - cudzołóstwa, zabójstwa, trucicielstwa, spiskowania przeciwko władzy państwowej (cesarzowi), fałszerstwa,

${ }^{1}$ K. Visky, Le divorce dans la legislation de Justinien, RIDA (23)1976, s. 249.

${ }^{2}$ C. 8,38(39),2 (Imp. Alexander A. Menophilo): Libera matrimonia esse antiquitus placuit...; zob. także D. $45,1,134$ pr.

${ }^{3} \mathrm{~J}$. Gaudemet, L'interprétation du principe d'indissolubilité du marriage chrétien au cours du premier millénaire, BIDR (81)1978, s. 12 I nn.; S. Kursa, Repudium i jego skutki prawne w świetle kodyfikacji Justyniana, CPH LXIV, z. 2, 2012, s. 65-68.

${ }^{4}$ Ibidem, s. 68-69. 
profanacji grobów, świętokradztwa, współdziałania z rozbójnikami lub udzielenia im schronienia, kradzieży zwierząt, zwłaszcza pociągowych, uprowadzenia ludzi wolnych, rozpusty na oczach żony z innymi kobietami, usiłowania zabicia żony z użyciem trucizny, miecza lub innego sposobu oraz wychłostania żony - dodał nową, którą stanowiło przystąpienie do buntu (seditio), zamieszczone w kontekście spiskowania przeciwko władzy państwowej.

Nov. 22,15,2 dawała możliwość porzucenia kobiety, jeżeli ta dopuściła się przestępstwa cudzołóstwa, trucicielstwa, zabójstwa, uprowadzenia, bezczeszczenia grobów, świętokradztwa, sprzyjania rozbójnikom, biesiadowania bez wiedzy lub wbrew woli męża z nieodpowiednimi osobami, nocowania wbrew jego zakazowi poza domem bez słusznego powodu albo uczestniczenia w widowiskach cyrkowych, teatralnych, usiłowania zabicia męża z użyciem trucizny, miecza lub w inny sposób, współdziałania w spisku, fałszerstwa, podniosła rękę na męża.

Obok powodów wymienionych w Nov. 22,15,2, ustanowionych wcześniej przez cesarza Teodozjusza II, Justynian wskazał w Nov. 22,16,1 trzy inne, które również pochodziły $\mathrm{z}$ dawnego prawa ${ }^{5}$ i umożliwiały legalne repudium kobiety, a mianowicie: rozmyślne przerwanie ciąży, lubieżną kąpiel z mężczyznami, rozpowiadanie o zamiarze zawarcia nowego małżeństwa podczas trwania węzła małżeńskiego.

$\mathrm{W}$ odniesieniu do pierwszej z wymienionych przyczyn, na podkreślenie zasługuje fakt dookreślenia pojęcia przerwania ciąży przez kobietę. W Nov. 22,16,1 Justynian wskazał, że powodem tym nie może być jakikolwiek abortus, lecz tylko taki, którego żona dokonała z premedytacją w celu zadania bólu mężowi (zasmucenia go) i pozbawienia go potomka (ex studio abortum faciat virumque contristet et privet spe filiorum). Repudium w tym przypadku usprawiedliwiał tylko abortus dokonany przez żonę cum malo dolo colorato. W konsekwencji, takim dopowiedzeniem Justynian zawęził możliwość powołania się na tę przyczynę przez męża. Analizując tę przyczynę, K. Visky nie zauważył, że chodzi tu o zawinione działanie ze strony kobiety, które jest skutkiem jej zepsucia (si enim mulier tanta teneatur nequitia), a nie, jak stwierdza, wielkiej niezgody między małżonkami ${ }^{6}$. Gdyby przyjąć jego opinię, abortus musiałby być obustronnie zawiniony. W tekście zaś, jak wskazano, chodzi jedynie o rozmyślne, dokonane z premedytacją, zawinione działanie kobiety.

Zarówno w C. 5,17,11,2, jak i w Nov. 22,16,1 Justynian nie wyjaśnił bliżej, na czym polegała kąpiel żony z mężczyznami. Jest rzeczą pewną, że nie

${ }^{5} \mathrm{~K}$. Visky utrzymuje, że wymienione w Nov. 22,16,1 przyczyny repudium stanowią nowość w legislacji Justyniana (,"la novelle 22 a créé d'autres causes de divorce”). Takie stwierdzenie nie odpowiada jednak prawdzie, ponieważ zostały one wprowadzone przez Justyniana już w C. 5,17,11,2. Por. K. Visky, Le divorce dans la legislation ..., s. 252.

${ }^{6}$ Ibidem. 
mogło chodzić o kąpiel z udziałem męża. Powstaje więc pytanie, gdzie żona mogła się kąpać z obcymi mężczyznami? Teoretycznie istniały różne możliwości - w domowej łazience (balneum) lub basenie (piscina), albo w publicznych pływalniach (piscinae publice) lub w plenerze. Generalnie Rzymianie rzadko zażywali kąpieli całego ciała, zazwyczaj czynili to raz na tydzień ${ }^{7}$. Nie bez powodu więc Justynian używa w tekście Nov. 22,16,1 wyrażenia cum viris voluptatis occasione lavetur. Okazja taka trafiała się zwłaszcza wtedy, kiedy kobiety udawały się do łaźni publicznych. Zwykle składały się one z dwóch sekcji - męskiej i żeńskiej. Tam zaś, gdzie nie było wydzielonych sekcji, obowiązywały różne godziny kąpieli dla mężczyzn i kobiet. Do wspólnej kąpieli kobiet z mężczyznami mogło dojść jedynie na pływalniach, które były przeznaczone dla obu płci. Jednakże zdaniem U.E. Paoli na pływalnie nie uczęszczały kobiety, które nie chciały narazić się na krytykę i podejrze$n^{8}{ }^{8}$. Biorąc pod uwagę inne określenia występujące w opisie kąpieli żony z mężczyznami, jakie znajdujemy zarówno w C. 5,17,11,2 (luxurosia est [...] libidinis causa), jak i w omawianej noweli (tanta libido est [...] voluptatis occasione), należy dodać, że jakkolwiek taka kąpiel była z natury rzeczy dwuznaczna, to jednak dopiero wtedy stawała się przyczyną usprawiedliwiającą repudium, gdy towarzyszyła jej żądza pozamałżeńskich doznań zmysłowych.

Trzeci z powodów, to jest rozpowiadanie o zamiarze zawarcia nowego małżeństwa podczas trwania węzła małżeńskiego, co do istoty pokrywał się $\mathrm{z}$ opisem tej przyczyny zawartym w C. 5,17,11,2 (dum est in matrimonio, alium meritum fieri sibi conata fuerit), jak również wskazywał na taki sam czas ujawnienia tego zamiaru przez kobietę, czyli podczas trwania legalnego małżeństwa (etiam dum adhuc constet cum viro matrimonium). Nową okolicznością dotyczącą tej przyczyny w Nov. 22,16,1 jest rozgłoszenie owego zamiaru wśród innych osób (ad alios de nuptis suis loquatur). Wprowadzenie takiej okoliczności przez Justyniana do tekstu prawnego zawęziło zakres tej przyczyny. Mąż mógł tym samym oddalić swoją żonę tylko wówczas, gdy poniżyła go ona w opinii publicznej rozgłaszając, iż zamierza wyjść za innego.

W Nov. 74,5 pr. Justynian unormował kwestię wyrzucania z domu kobiet, którym mężczyźni złożyli pod przysięgą obietnicę w swoich domach dotykając świętych pism albo w domach modlitwy, że będą ich legalnymi żonami i matkami dzieci prawego łoża (ut uxorem legitimam haberet filiorum legitimorum matrem). W każdym przypadku, gdy kobieta została przyjęta do domu mężczyzny z taką obietnicą, mężczyźnie nie wolno było jej bezpodstawnie (inrationabiliter) wypędzić $\mathrm{z}$ domu. $\mathrm{W}$ razie bezpodstawnego wypędzenia kobiety z domu, należało traktować ją jak legalną żonę, jeżeli udowodniła, że miała podstawy za taką uchodzić. Przysługiwało jej wtedy prawo do dokona-

\footnotetext{
${ }^{7}$ E. Saglio, s.v. Balneum, balneae, w: DAGR 1.1, s. 651.

${ }^{8}$ U.E. Paoli, Vita Romana, Firenze 1948, s. 293.
} 
nia repudium propter iustam causam, jaką w tym przypadku stanowiło niedotrzymanie złożonej przez mężczyznę przysięgi zawarcia małżeństwa.

W Nov. 117 Justynian postanowił ponownie zreorganizować całą materię dotyczącą rozwiązywania małżeństw w drodze repudium. Nauczony doświadczeniem doszedł do wniosku, że wymienione w dawnym prawie cywilnym, a także w jego konstytucjach, przyczyny usprawiedliwiające rozwiązanie małżeństwa były zbyt liczne i nadmiernie ułatwiały dokonywanie repudiów. Dlatego zdecydował się na dokonanie ich redukcji. Przyznał mianowicie mężowi prawo do jednostronnego oddalenia żony tylko z siedmiu powodów, a żonie zaś jedynie z pięciu.

W myśl Nov. 117,8 kobieta dostarczała mężczyźnie usprawiedliwionej przyczyny swojego oddalenia, gdy: 1) wiedziała, że niektóre osoby spiskują przeciwko władzy państwowej (cesarza), jednak nie powiadomiła o tym nawet swojego męża9; 2) oskarżona o cudzołóstwo przez męża została za nie skazana $^{10}$; 3) usiłowała pozbawić życia męża albo wiedząc o tym, że inni nastają na jego życie, nie wskazała ich mężowi ${ }^{11}$; 4) wbrew woli męża biesiadowała z obcymi mężczyznami ${ }^{12}$; 5) wbrew woli męża zażywała z nimi kąpieli ${ }^{13}$; 6) wbrew woli męża przebywała poza domem, z wyjątkiem domu jej własnych rodziców ${ }^{14}$; 7) bez wiedzy męża lub wbrew jego zakazowi udawała się na widowiska cyrkowe, teatralne lub amfiteatralne ${ }^{15}$.

Nie stanowiły odtąd powodu dokonania repudium inne przyczyny, określone wcześniej w C. 5,17,8,3 i C. 5,17,11,2, a następnie w Nov. 22,15,2 i Nov. 22,16,1.

W Nov. 117,9 Justynian pozwolił kobiecie na usprawiedliwione oddalenie męża $\mathrm{w}$ drodze repudium $\mathrm{z}$ następujących powodów: 1) jeżeli mąż spiskował przeciwko władzy państwowej (cesarza) albo wiedząc o spisku nie doniósłby osobiście lub przez inną osobę na spiskujących ${ }^{16}$; 2) jeżeli w ja-

${ }^{9}$ Nov. 117,8,1: Si contra imperium cogitantibus aliquibus conscia est mulier aut etiam suo viro non iudicet...

${ }^{10}$ Nov. 117,8,2: Si de adulterio maritus putaverit posse suam uxorem convinci, oportet, virum prius inscribere mulierem aut etiam adulterum, et si huiusmodi accusatio verax ostenditur...

${ }^{11}$ Nov. 117,8,3: Si quolibet modo mulier vitae viri fuerit insidiata, aut aliis hoc facientibus conscia viro non indicaverit.

${ }^{12}$ Nov. 117,8,4: Si cum viris nolente marito extraneis convivit...

${ }^{13}$ Nov. 117,8,4: ... aut cum eis lavatur.

${ }^{14}$ Nov. 117,8,5: Si nolente viro foris domum manserit, nisi forsan apud proprios parentes. Jednakże gdyby zgodnie z Nov. 117,8,7 zdarzyło się, że mężczyzna wyrzucił swoją żonę z własnego domu bez zaistnienia którejś z przyczyn wymienionych w Nov. 117,8, a ona nie mając rodziców, do których mogłaby się udać, z konieczności spędziłaby noc poza domem, mężczyzna tracił prawo do repudium, ponieważ on sam był powodem zaistniałego stanu rzeczy.

${ }^{15}$ Nov. 117,8,6: Si circensibus aut theatris aut amphitheatris interfuerit ad spectandum ignorante aut prohibente viro.

${ }^{16}$ Nov. 117,9,1: Si contra imperium aut ipse cogitaverit aliquid aut cogitantibus conscius non indicaverit imperio aut per se aut per quamcumque personam. 
kikolwiek sposób usiłował pozbawić żonę życia, albo wiedząc o tym, że inni mają taki zamiar, nie uprzedził żony i nie dążył do ich ukarania zgodnie z prawem ${ }^{17}$; 3) jeżeli mąż naraził swoją żonę na utratę czystości usiłując oddać ją obcym w celach cudzołożnych ${ }^{18}$; 4) jeżeli mąż pisemnie oskarżył żonę o popełnienie cudzołóstwa, którego nie udowodnił ${ }^{19}$; 5) jeżeli mąż wzgardziwszy żoną, sprowadził do wspólnego domu inną kobietę albo w tym samym mieście $\mathrm{w}$ innym domu utrzymywał częste kontakty $\mathrm{z}$ inną kobietą i nie zaprzestał tego rodzaju rozwiązłości, mimo dwukrotnego upomnienia ze strony rodziców lub teściów, albo innych osób godnych zaufania ${ }^{20}$.

Zestawiając katalogi przyczyn usprawiedliwionego repudium męża przez żonę, należy stwierdzić, że spośród czternastu przewidzianych w Nov. 22,15,1 Justynian w Nov. 117,9 zachował trzy, to jest: spiskowanie przeciwko władzy państwowej, usiłowanie zabicia żony i rozwiązłość pozamałżeńską, z tym że powołanie się żony na tę ostatnią przyczynę uzależnił od dwukrotnego bezskutecznego upomnienia męża ze strony rodziny lub osób trzecich. Derogacja usprawiedliwionych przyczyn repudium męża przez żonę objęła również niedotrzymanie przysięgi małżeńskiej, o której była mowa w Nov. 74,5 pr. Wprowadził jednak dwie inne przyczyny - usiłowanie oddania żony obcym mężczyznom w celach cudzołożnych oraz nieudowodnione oskarżenie jej o cudzołóstwo.

Należy zauważyć, że przewidziane w Nov. 117,8-9 usprawiedliwione przyczyny jednostronnego oddalenia współmałżonka, zredukowane z siedemnastu do siedmiu na rzecz męża i z piętnastu do pięciu na rzecz żony, generalnie miały swoje źródło w niestosownym zachowaniu się jednego małżonka względem drugiego. Wyjątek stanowiło spiskowanie przeciwko władzy państwowej ${ }^{21}$.

Chociaż redukcja tych przyczyn była znaczna, bo przekraczała połowę uwzględnionych w Kodeksie, cesarz Justynian nie zdobył się na całkowity zakaz dokonywania repudium.

W odróżnieniu od doktryny Kościoła katolickiego wyrażanej ustami Ojców Kościoła, w myśl której cudzołóstwo, zarówno męża jak i żony, było jednakowo ciężkim grzechem, przyzwolenie kobiecie na dokonanie repudium męża, który dopuścił się niewierności względem niej, Justynian uwarunkował

${ }^{17}$ Nov. 117,9,2: Si quolibet modo vir insidiatus fuerit vitae mulieris, aut aliis hoc volentibus sciens non manifestaverit uxori et studuerit secundum leges ulcisci.

${ }^{18}$ Nov. 117,9,3: Si maritus uxoris castitati insidiatus aliis eam adulterandam temptaverit tradere.

${ }^{19}$ Nov. 117,9,4: Si vir de adulterio inscripserit uxorem et adulterium non probaverit...

${ }^{20}$ Nov. 117,9,5: Si quis in sua domo, in qua cum sua coniuge commanet, contemnens eam cum aliis inveniatur in ea domo manens, aut in eadem civitate degtens in alia domo cum alia muliere frequenter manere convincitur, et semel et secundo culpatus aut per suos parentes aut per mulieris aut per alias aliquas fide dignas personas huiusmodi luxuria non abstinuerit...

${ }^{21} \mathrm{~K}$. Visky, Le divorce dans la legislation..., s. 254, B. Biondi, Il diritto romano cristiano, t. III, Milano 1954, s. 181. 
dodatkowymi okolicznościami, takimi jak permanentne trwanie w cudzołóstwie i konieczność napomnień ze strony osób trzecich. Z dzisiejszego punktu widzenia takie rozwiązanie prawne można uznać za dyskryminujące kobiety, lecz należy pamiętać, że w epoce justyniańskiej mężczyźnie wciąż zwyczajowo przyznawano większą wolność w sferze obyczajowej.

II. Rozpoczętą w Kodeksie regulację rozwiązywania małżeństw bona gratia Justynian kontynuował w Nov. 22 oraz 117, by ostatecznie zamknąc tę kwestię w Nov. 123.

Po wymienieniu w Nov. 22,4 różnych sposobów rozwiązywania małżeństw i podkreśleniu, że istnieje również sposób rozwiązania małżeństwa bona gratia, w kolejnych rozdziałach tejże noweli opisał szczegółowo przypadki, w których tego rodzaju rozumna rezygnacja z małżeństwa była możliwa. V. Arangio-Ruiz zauważa, że każdy z tych przypadków uniemożliwiał osiągnięcie normalnych celów małżeństwa ${ }^{22}$. Zdaniem zaś M. Wójcik w każdym z tych przypadków chodziło o przyczynę, która uniemożliwiała wspólne życie i trwanie małżeństwa ${ }^{23}$.

W Nov. 22,5 jako pierwszy powód dokonania repudium bona gratia wymienia wstąpienie jednego z małżonków do klasztoru. Powołuje się tam na swoją wcześniejszą konstytucję, w której zezwolił na porzucenie małżeństwa, zarówno mężczyźnie, jak i kobiecie, jeżeli dokonali wyboru „lepszej drogi życia dążąc do czystości" (meliorem migrans viam et sub castitate conversationem concupiscens). Z analizy źródeł wynika, że konstytucją tą była konstytucja Justyniana z 531 roku. Odnośny jej fragment został zamieszczony w C. 1,3,52,15, gdzie wyraźnie zaznaczono, że repudium, nazywanego bona gratia, dokonywał w tym przypadku współmałżonek, który nie wybrał życia zakonnego (repudium quod 'bona gratia' dicunt mittatur ab eo qui religiosam vitam non elegerit). W Nov. 22,5 Justynian nie wprowadził żadnych nowych elementów do istniejącego stanu prawnego, co oznacza, że na etapie jej obowiązywania opuszczony współmałżonek, jeżeli chciał zawrzeć nowe małżeństwo, musiał dokonać formalnego repudium, bez względu na to, ile czasu upłynęło od wstąpienia jego partnera do klasztoru.

Spostrzeżenie B. Biondiego, że w Nov. 22,5 wstąpienie do klasztoru porównane zostało do śmierci ${ }^{24}$, choć prawdziwe, nie uzasadnia tezy, że chodzi w niej o rozwiązanie małżeństwa bez dokonania repudium, gdyż w odniesieniu do rozliczeń majątkowych analogiczne słowa odnajdujemy także we wcze-

${ }^{22}$ V. Arangio-Ruiz, Istituzioni di diritto romano, Napoli 2002, s. 451.

${ }^{23}$ M. Wójcik, Wstapienie do klasztoru jako przyczyna ustania matżeństwa w prawie rzymskim, [w:] Wokót problematyki malżeństwa w prawie rzymskim. Henrico Insadowski (1888-1946) in memoriam, red. A. Dębiński, M. Wójcik, Lublin 2007, s. 185.

${ }^{24}$ B. Biondi, Il diritto romano cristiano..., s. 184; por. H.J. Wolf, Doctrinal trends in postclassical roman marriage law, ZSS 67 (1950), s. 271. 
śniejszej konstytucji Justyniana (C. 1,3,52,15), a mimo to jest tam mowa o repudium quod bona gratia dicunt. O tym, że w Nov. 22,5 chodzi o rozwiązanie małżeństwa z mocy samego prawa (vi iuris) jest również przekonany O. Robleda $^{25}$. Trudno się jednak z ich opinią zgodzić, ponieważ konieczność dokonania repudium wskutek złożenia ślubów zakonnych została zniesiona dopiero w Nov. 123,40 z roku $546^{26}$. Czytamy tam: Si vero constante adhuc matrimonio aut vir solus aut uxor sola intraverit in monasterium, solvatur matrimonium et citra repudium, postquam tamen persona pergens ad monasterium schema perceperit... (Jeżeli zaś podczas trwania małżeństwa wstąpiłby do klasztoru albo sam mąż, albo sama żona, małżeństwo ustaje i bez dokonania repudium, jednak dopiero z chwilą, gdy osoba wstępująca do klasztoru przywdzieje habit...). W noweli tej Justynian wyraźnie zaznaczył, że po złożeniu profesji zakonnej i przywdzianiu habitu dokonanie repudium nie było już konieczne, ponieważ małżeństwo ustawało z mocy samego prawa (solvatur matrimonium et citra repudium $)^{27}$. Powstaje jednak pytanie, co się działo, jeżeli opuszczony małżonek chciał zawrzeć małżeństwo przed złożeniem profesji zakonnej przez swojego partnera, czyli na etapie jego nowicjatu, który trwał trzy lata ${ }^{28}$. Należy pamiętać, że w tym czasie wciąż istniało jego małżeństwo z osobą, która wstąpiła do klasztoru. Wydaje się, że skoro Justynian w przywołanej noweli nie wprowadził żadnych zmian, to wynika z tego, że opuszczonemu małżonkowi nadal przysługiwało prawo do niezawinionego oddalenia $\mathrm{w}$ drodze repudium małżonka, który poddał się próbie życia zakonnego.

Z kolei w Nov. 22,6, przywołując wcześniejszą konstytucję (C. 5,17,10) Justynian zezwolił kobiecie lub jej rodzicom na dokonanie repudium, gdyby się okazało, że jej mąż nie był w stanie odbyć z nią stosunku seksualnego, czyli z powodu jego impotencji. Jednakże w odróżnieniu do C. 5,17,10 zezwolił im na dokonanie repudium w takim przypadku nie po upływie dwóch, lecz trzech lat od rozpoczęcia pożycia małżeńskiego ${ }^{29}$. Justynian uzasadnił tę zmianę tym, że w przeszłości zdarzało się, że mężowie płodzili dzieci nawet po upływie dwóch lat.

${ }^{25} \mathrm{O}$. Robleda, El matrimonio en derecho romano. Esencia, requisitos de validez, effectos, disolubilidad, Roma 1970, s. 271.

${ }^{26}$ W. Osuchowski, Zarys rzymskiego prawa prywatnego, Warszawa 1971, s. 295.

${ }^{27}$ M. Wójcik słusznie stwierdza, że małżonek dążący do utrzymania swojego małżeństwa musiał się pogodzić z jego rozwiązaniem z mocy prawa, jeżeli drugi współmałżonek złożył śluby zakonne; zob. M. Wójcik, Wstapienie do klasztoru jako przyczyna ustania matżeństwa, s. 186. Podobnie zob. J. Misztal-Konecka, Bigamia ..., s. 150.

${ }^{28}$ Nov. 5,2 pr.: ... Sancimus igitur sacras sequentes regulas, eos qui singularem conversationem profitentur, non prompte mox a reverentissimis praesulibus venerabilium monasteriorum habitum percipere monachilem, sed per triennium totum (sive liberi forte sive servi sint) tolerare, nondum monachicum habitum promerentes, sed tonsura et veste eorum qui laici vocantur uti, et manere divina discentes eloquia...

${ }^{29}$ Nov. 22,6: ... Hanc itaque legem corrigimus brevi quadam adiectione: non enim biennium numerari solum ex ipso tempore copulationis, sed triennium volumus... 
Z użytego w Nov. 22,6 wyrażenia impotens fuerit coire mulieri (okazałby się niezdolnym do współżycia seksualnego z żoną) wynika, że powodu do repudium dostarczała względna niemoc płciowa po stronie mężczyzny, czyli niezdolność do dokonania stosunku seksualnego z jego żoną. Z uzależnienia zaś możliwości dokonania repudium od upływu trzech lat pożycia małżeńskiego nasuwa się wniosek, iż niemoc ta nie mogła być przejściowa, lecz winna być nacechowana trwałością. W Nov. 22,6 nie ma żadnej wzmianki na temat podłoża niemocy płciowej, czy miała ona charakter organiczny, czy też psychiczny, wydaje się jednak, że skoro nie zostało to doprecyzowane, nie miało istotnego znaczenia dla dokonania repudium. Ponadto, Justynian dostrzegając, że sytuacja mężczyzny dotkniętego impotencją nie była komfortowa, zaznaczył, że prawo do repudium przysługuje żonie lub jej rodzicom, jeżeli sam mężczyzna nie chciał go dokonać (vel si noluerit hoc maritus). Oznacza to, że również mężczyzna był uprawniony do dokonania repudium $\mathrm{w}$ takiej sytuacji $\mathrm{i}$ to stanowiło novum w stosunku do C. 5,17,10.

Według Nov. 22,14 trzecim, dopuszczonym już w C. 5,17,7 motywem dokonania repudium bona gratia było faktyczne opuszczenie żony przez żołnierza. Motyw ten pojawił się już znacznie wcześniej w konstytucji cesarza Konstantyna z 337 roku, której treść Justynian przywołuje także w Nov. 22,14. Według tej konstytucji kobieta, której mąż udał się na wyprawę wojenną i milczał przez cztery lata, nie dając oznak życia, mogła zawrzeć powtórne małżeństwo po potwierdzeniu otrzymania przez naczelnika wojska przedłożonego mu libellum. Justynian w Nov. 22,14 uznał, że takie rozwiązanie prawne nie było dojrzałe, ponieważ jego zdaniem dla męża zajętego sprawami wojskowymi utrata żony już po czterech latach byłaby nie mniejszą karą niż wzięcie do niewoli wojennej. $Z$ tego powodu nie pozwolił kobiecie na powtórne zamążpójście wcześniej jak po upływie dziesięciu lat, gdy konsekwentnie wysyłała mu listy lub przez innych przekazywała wiadomości, on zaś albo otwarcie nie wyrażał zgody na jej małżeństwo, albo całkowicie milczał. Wówczas miała prawo przedłożyć libellum dowódcy wojska, wodzowi armii lub trybunowi, którzy byli zwierzchnikami męża. Dopiero po spełnieniu tych formalności miała prawo przesłania prośby do cesarza i ponownego zamążpójścia.

Tak więc Justynian z jednej strony poszerzył zakres podmiotów kompetentnych do przyjęcia libellum, a z drugiej wydłużył o sześć lat okres oczekiwania, po którym mogło ono być złożone. Wziął tym samym w ochronę interes żonatego żołnierza, który składając przysięgę wojskową (sacramentum), w obecności konsulów lub namiestników zobowiązywał się do udziału w dziesięciu wyprawach konno lub dwudziestu pieszo ${ }^{30}$, co pokrywało się z okresem dziesięciu lub dwudziestu lat ${ }^{31}$.

\footnotetext{
${ }^{30}$ F. Terlikowski, Życie publiczne, prywatne i umystowe starożytnych Rzymian, Lwów 1925, s. 50

${ }^{31}$ G. Hacquard, J. Dautry, O. Maisani, Guide romain antique, Paris 1998, s. 65.
} 
Opisany w Nov. 22,14 przypadek Justynian zamieścił wcześniej w Kodeksie w tytule siedemnastym księgi piątej De repudiis et iudicio de moribus sublato $(\mathrm{O}$ jednostronnych oddaleniach i o zniesieniu powództwa $\mathrm{z}$ obyczajów). Chociaż więc w treści Nov. 22,14 po terminie libellus nie występuje przydawka repudii, należy wnosić, że w tym przypadku małżeństwo ustawało na skutek pisemnego jednostronnego oddalenia męża, czyli na skutek sporządzenia libellum repudii, mimo że ten list „rozwodowy” mógł bezpośrednio nie dotrzeć do niego lub sam z nim się nie zapoznał ${ }^{32}$.

Wszystkie wyżej wymienione przypadki rozwiązania małżeństwa w drodze repudium Justynian zaliczył do sposobów rozwiązania małżeństwa bona gratia. Istnieje jednak między nimi istotna różnica, bowiem pierwszy i drugi $\mathrm{z}$ nich znajdują swoją legitymację w samym prawie stanowionym przez cesarza, trzeci natomiast wymagał zatwierdzenia przez niego.

Byłoby jednak błędem sądzić, że w Nov. 22 Justynian ograniczył rozwiązanie małżeństwa bona gratia tylko do wymienionych wyżej trzech przypadków, które wymagały dokonania repudium. Uporządkował w niej bowiem także inne stany faktyczne, które ipso iure powodowały rozwiązanie małżeństwa bona gratia w dawnym prawie. Należały do nich: popadnięcie w niewolę u wrogów ${ }^{33}$, skazanie na pracę w kopalni ${ }^{34}$, skazanie na deportację ${ }^{35}$. Jednak zdaniem Justyniana dwa ostatnie stany nie usprawiedliwiały rozwiązania małżeństwa. Argumentował to tym, że kara wymierzona osobie wolnej nie czyni $\mathrm{z}$ niej niewolnika i w konsekwencji nie powoduje ustania jej małżeństwa ${ }^{36}$.

W ślad za dawnym prawem (D. 24,2,6) Justynian nakazał w Nov. 22,7 traktować małżeństwo osoby popadłej w niewolę wojenną za nadal istniejące przez okres pięciu lat od chwili utraty przez nią wolności. Po ich upływie małżeństwo to ustawało z mocy samego prawa, a osoba wolna miała prawo zawrzeć ponowne małżeństwo bez konieczności dokonania repudium ${ }^{37}$, bez względu na to, czy została stwierdzona śmierć jej współmałżonka, czy pozostała co do tego niepewnośćc ${ }^{38}$.

Rozwiązanie małżeństwa $\mathrm{z}$ mocy samego prawa następowało również w myśl Nov. 22,9 wskutek wyroku sądowego orzekającego ponowne popadnięcie w niewolę osoby wyzwolonej. Zdaniem Justyniana w tym przypadku zachodziła analogia między popadnięciem w niewolę a śmiercią, w wyniku której z natury rzeczy ustawało każde małżeństwo.

${ }^{32}$ Zob. C. $5,17,6$.

${ }^{33}$ Nov. $22,7$.

${ }^{34}$ Nov. 22,8 .

${ }^{35}$ Nov. 22,13 .

${ }^{36}$ Nov. 22,8: ...Nos autem haec curavimus, et nullum ab initio bene natorum ex supplicio permittimus fieri servum...

${ }^{37}$ Nov. 22,7: ... hic neque repudio fiat opus...

${ }^{38}$ B. Biondi, Il diritto Romano cristiano..., s. 184. 
W Nov. 22,10 Justynian wyjaśnił, że za przesłankę rozwiązania małżeństwa bona gratia nie można uważać zawarcia małżeństwa $\mathrm{z}$ osobą niewolną w przekonaniu, że jest ona osobą wolną, ponieważ z powodu nierówności stanu osób w ogóle do niego nie doszło. Innymi słowy takie matrimonium było nullum jako zawarte pod wpływem błędu co do przymiotu osoby nupturienta (error qualitatis qui redundet in errorem personae) $)^{39}$.

Jednakże w myśl Nov. 22,11, jeżeli właściciel niewolnika lub niewolnicy zgodził się na wyzwolenie takiej osoby w celu poślubienia osoby wolnej i nie dotrzymując danego słowa, zaskarżył ważność takiego małżeństwa albo wiedząc o zamierzanym małżeństwie w żaden sposób mu się nie sprzeciwił po to, by je później zaskarżyć, mimo późniejszego sprzeciwu z jego strony, małżeństwo takich osób należało uważać za ważne ${ }^{40}$. Co więcej, Justynian nakazał także dzieci z takiego małżeństwa traktować jako wolne i wolnourodzone ${ }^{41}$.

Według Nov. 22,12 zgoda byłego właściciela na zawarcie małżeństwa przez porzuconego $\mathrm{w}$ chorobie albo z nienawiści, czy też wypędzonego z jego dominium niewolnika lub niewolnicę, nie miała żadnego znaczenia. Ich małżeństwa między sobą lub $\mathrm{z}$ innymi osobami wolnymi były ważne $\mathrm{z}$ tej racji, że skutkiem porzucenia, czy wyrzucenia, uzyskiwali oni wolność. Justynian poczuł się odpowiedzialny za małżeństwa takich osób do tego stopnia, że expressis verbis zabronił byłym panom ingerowania w te związki (non in posterum inquietabuntur ab his).

Do kwestii rozwiązania małżeństwa bona gratia Justynian powrócił w Nov. 117,12, gdzie analogicznie, jak w regulacji dotyczącej repudium propter iustam causam, dokonał redukcji możliwości rozwiązania małżeństwa z powodu niezawinionej przyczyny do trzech przypadków: niemocy płciowej mężczyzny, wstąpienia do klasztoru oraz popadnięcia w niewolę u wrogów, w stosunku do których utrzymał wcześniejsze dyspozycje prawa (in his enim tribus casibus quae de eis prioribus nostris legibus continentur firma esse

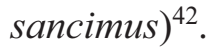

${ }^{39}$ Błąd co do stanu wolności osoby nupturienta czynił małżeństwo z niewolnikiem (niewolnicą) zarówno w prawie rzymskim, jak i kanonicznym, nieważnym. Na takim stanowisku stał jeszcze Kodeks Prawa Kanonicznego z 1917 roku, który obowiązywał do 1983 roku. Zob. kan. $1083 \S 2$ : Error circa qualitatem personae, etsi det causam contractui, matrimonium irritat tantum: [...] 2. Si persona libera matrimonium contrahat cum persona quam liberam putat, cum contra sit serva, servitute proprie dicta. (Błąd co do przymiotu osoby, chociażby wpłynął na zawarcie małżeństwa, unieważnia je tylko wówczas: [...] 2. Jeżeli osoba wolna zawiera małżeństwo z osobą, którą uważa za wolną, gdy w rzeczywistości jest stanu niewolnego, w ścisłym tego słowa znaczeniu).

${ }^{40}$ Zachodzi tu zgodność z podejściem Kościoła katolickiego do małżeństw osób wolnych z niewolnikami, które prawo kanoniczne uważało za ważne od czasów papieża Kaliksta I. Zob. M. Żołnierczuk, Zarys prawa rzymskiego, Lublin 1995, s. 73.

${ }^{41}$ Nov. 22,11: ... etiam filii ex talibus nuptiis liberi et ingenui secundum hanc nostram erunt legem.

${ }^{42} \mathrm{P}$. Bonfante, chociaż poprawnie wymienia te trzy przyczyny rozwiązania małżeństwa, bezpodstawnie jednak zalicza niewolę u wrogów, która po upływie pięciu lat $\mathrm{z}$ mocy prawa powodo- 
Mocą tej konstytucji Justynian zniósł zaś pozostałe przyczyny rozwiązania małżeństwa bona gratia wymienione w Nov. $22^{43}$, a mianowicie rozwiązanie małżeństwa ipso iure wskutek wyroku sądowego orzekającego ponowne popadnięcie $\mathrm{w}$ niewolę wyzwoleńca oraz jednostronne oddalenie męża przez żonę, z którą mąż odbywający służbę wojskową nie utrzymywał żadnych kontaktów przez okres dziesięciu lat ${ }^{44}$. Jednakże w świetle Nov. 117,11 małżeństwo żołnierza pełniącego misję wojskową ustawało z mocy samego prawa, jeżeli żona otrzymała oficjalne potwierdzenie ze strony władz wojskowych, że jej mąż nie żyje. Ze względu na tempus lugendi mogła ona zawrzeć małżeństwo z innym mężczyzną dopiero po upływie roku od otrzymania wspomnianego potwierdzenia.

Weryfikacja śmierci żołnierza opierała się na zeznaniach świadków składanych pod przysięgą. W przypadku krzywoprzysięstwa, gdy okazało się, że żołnierz żyje, groziła im kara dymisji i zapłaty dziesięciu funtów złota. Wówczas żołnierzowi, jeśli chciał, przysługiwało prawo ponownego zawarcia małżeństwa z byłą żoną (ipse vero licentiam habeat, si voluerit, suam uxorem recipere $)^{45}$. Na tej podstawie można wnosić, że również małżeństwo takiej kobiety z innym mężczyzną, jeśli chciała wrócić do byłego męża (żołnierza), ustawało bona gratia $\mathrm{z}$ mocy samego prawa. $\mathrm{Z}$ woli Justyniana takie rozwiązanie prawne odnosiło się do wszystkich osób zatrudnionych w wojsku ${ }^{46}$.

III. Ogólny zakaz rozwiązywania małżeństw bez słusznej przyczyny, wyrażony wcześniej w C. 5,17,8,1, został utrzymany w mocy w Nov. 22,15,3.

Następnie Justynian podtrzymał w Nov. 22,19 zakaz jednostronnego rozwiązywania małżeństw przez niepełnoletnich obojga płci znajdujących się pod władzą ojcowską lub emancypowanych, wyrażony wcześniej w C. 5,17,12. Do takiej regulacji prawnej zmotywował Justyniana stan faktyczny, a miano-

wała ustanie małżeństwa, do przyczyn repudium. Zob. P. Bonfante, Istituzioni di diritto Romano, Torino 1946, s. 193. Podobnie zob. H. Insadowski, Rzymskie prawo malżeńskie a chrześcijaństwo, Lublin 1935, s. 298; J. Misztal-Konecka, Bigamia w prawie rzymskim, Lublin 2011, s. 183.

${ }^{43}$ Nov. 117,12: ... reliquas autem omnes vacare praecipimus, nullamque aliam causa citra eas quae nominatim insertae sunt huic legi posse solvere legitimum matrimonium, sive nostris sive veteribus legibus continetur.

${ }^{44}$ A. Gauthier, omawiając kwestię możliwości rozwiązania małżeństwa w Nov. 117 z powodu niezawinionej przyczyny (bona gratia), stwierdza, że Justynian zniósł tam jednocześnie stare powody rozwiązania małżeństwa, a mianowicie niewolę za karę i deportację, tymczasem Justynian zniósł możliwość rozwiązania małżeństwa z tych powodów już w Nov. 22. Nic natomiast nie wzmiankuje o zniesieniu w Nov. 117 możliwości rozwiązania małżeństwa wskutek wyroku sądowego orzekającego ponowne popadnięcie w niewolę wyzwoleńca oraz z powodu nieutrzymywania kontaktów przez żołnierza ze swoją żoną. Zob. A. Gauthier, Le droit romain et son apport à l'édification du droit canonique, Ottawa 1996, s. 46.

${ }^{45}$ Nov. 117,11. Udzielenie tego upoważnienia żołnierzowi dowodzi, że jego małżeństwo ustało. W przeciwnym razie takie upoważnienie byłoby zbędne.

${ }^{46}$ Nov. 117,11: ... His observandis et circa alios omnes qui in armata militia referenttur. 
wicie zdarzało się, że małoletni małżonkowie fikcyjnie z błahego powodu zrywali małżeństwo, żeby zobowiązać swoich rodziców do wydania posagu lub darowizny ante nuptias, podczas gdy w rzeczywistości ukradkiem się spotykali. Aby zaradzić tego rodzaju nadużyciom, przez które wyrządzano szkodę rodzicom, Justynian postanowił, że należy wymagać ich zgody nie tylko przy zawarciu małżeństwa przez ich małoletnie dzieci, lecz również do dokonania przez nich repudium. Gdyby jednak doszło do repudium bez zgody rodziców, zakazał nieletnim żądania wydania posagu, czy darowizny ante nuptias, tytułem kary za bezprawne rozwiązanie małżeństwa. W uzasadnieniu swojej decyzji powołał się na małoletniość, którą cechuje brak dojrzałości w podejmowaniu rozważnych decyzji, które przyniosłyby im pożytek i nie powodowały szkód wobec rodziców oraz tradycję sięgającą czasów Marka Aureliusza.

Z Nov. 22,19 wynika, że Justynian dokonywane przez małoletnich repudia bez żadnej słusznej przyczyny, a jedynie w celu wejścia w posiadanie darowizn przedmałżeńskich lub posagu, traktował jako pozorne rozwiązanie małżeństwa (quasi soluto matrimonio). Z faktu, że Justynian nie uznał fikcyjnych repudiów za rzeczywiste rozwiązanie małżeństwa, nie można jednak wnosić, że dokonane bez słusznej przyczyny celowe rozwiązanie małżeństwa $\mathrm{z}$ niskich pobudek materialnych nie było skuteczne ${ }^{47}$. Tak samo repudium dokonanego przez małoletnich bez zgody rodziców nie można uważać za nieważne $^{48}$. Gdyby założyć, że takie repudium było nieważne, bezcelowe byłoby dążenie małoletnich do obejścia prawa, a także bezprzedmiotowa byłaby sankcja karna, w myśl której wspomniane dobra nie trafiały do rąk tych osób małoletnich, które bez powodu oddaliły swojego małżonka.

Zakaz jednostronnego rozwiązywania małżeństw bez prawnej przyczyny Justynian podtrzymał w trzech dalszych nowelach 117,13, 127,4 i 134,11.

W Nov. 117,13 Justynian zabronił dokonywania repudium, jeżeli nie dało się go usprawiedliwić żadną z przyczyn wymienionych w poprzednich rozdziałach tej noweli, gdzie wymienił przypadki repudium propter iustam causam i repudium bona gratia. Należy zauważyć, że przeprowadzona w Nov. 117 radykalna redukcja usprawiedliwionych przyczyn repudium oraz przypadków rozwiązywania małżeństw bona gratia była ostatnią, jakiej dokonał Justynian w tej materii.

$\mathrm{Na}$ coraz bardziej negatywne podejście do repudium wskazuje również gradacja negatywnych ocen ferowanych w stosunku do repudium sine cau-

${ }^{47}$ J. Misztal-Konecka, komentując Nov. 22,19, uważa, że Justynian wykluczył ustanie małżeństwa z niskich pobudek materialnych. Zob. J. Misztal-Konecka, Bigamia..., s. 152.

${ }^{48}$ Przedmiotem regulacji prawnej Justyniana w Nov. 22,19 nie była kwestia ważności dokonanego repudium, jak widzi to $\mathrm{H}$. Insadowski, lecz ograniczenie repudiów sine causa w przypadku osób małoletnich. Wzmiankowana w Nov. 22,19 konieczność uzyskania przez nich zgody rodziców nie była wymagana do ważności repudium, lecz warunkowała ona odzyskanie przez małoletnich repudiantów posagu lub darowizny przedmałżeńskiej. Zob. H. Insadowski, Rzymskie prawo matżeńskie..., s. 298. 
sa, jakie spotykamy w nowelach. W Nov. 117,13 Justynian widzi w repudium skutek trwania $\mathrm{w}$ bezbożnym zamiarze (si vero permanserit in huiusmodi impia voluntate et repudium marito transmiserit), natomiast w Nov. 127,49 i Nov. $134,11^{50}$ określa je expressis verbis mianem deliktu.

IV. Skutki prawne rozwiązania małżeństwa inter vivos per modum repudii zależały od rodzaju dokonanego jednostronnego oddalenia współmałżonka i w różnym stopniu dotyczyły ich sprawców oraz dzieci rozdzielonych małżonków.

1. Skutki majątkowe dotyczące małżonków i ich potomstwa

Zawinione rozwiązanie małżeństwa rodziło mniejszą lub większą dolegliwość w postaci majątkowych sankcji karnych, które dotykały stronę winną jego rozpadu. Przy repudium propter iustam causam ponosił je małżonek, który dał powód do jego dokonania, zaś w przypadku repudium sine causa ten, który odważył się go dokonać wbrew zakazowi prawa. Sankcji karnych nie pociągało za sobą repudium bona gratia.

1.1. Penalizacji zachowań małżonka winnego rozpadu małżeństwa dotyczyły Nov. 22, Nov. 74 i Nov. 117.

W świetle Nov. 22,15,1, Nov. 22,15,2 i Nov. 22,16,1 małżonek winny rozpadu małżeństwa tracił na rzecz strony niewinnej przysporzenia majątkowe związane z zawarciem małżeństwa, to jest posag i darowiznę ante nuptias.

Jeżeli doszło do zawinionego rozpadu małżeństwa zawartego bez ustanowienia posagu, winny małżonek był zobowiązany oddać stronie niewinnej jedną czwartą wartości swojego majątku po odliczeniu długów, o ile jego wartość nie przekraczała czterystu funtów złota. Gdy zaś przekraczała tę sumę, należało jej wypłacić sto funtów złota ${ }^{51}$.

Podobna zasada obowiązywała według Nov. 74,5 pr. w przypadku wyrzucenia z domu kobiety, której mężczyzna przysiągł zawarcie małżeństwa oraz że będą mieli ze sobą potomstwo prawego łoża. W takim przypadku mężczy-

${ }^{49}$ Nov. 127,4: ... si sine causa nostrae legi cognita matrimonia distrahunt, etiam viros subdi hoc praesumentes, et similes esse poenas in viro et muliere. In delicto enim aequali proximas eis imminere poenas iustum putavimus esse.

${ }^{50}$ Nov. 134,11 pr.: Quia vero aliqui nostram legem transcendere student, in qua evidenter causas enumeravimus ex quibus solum repudia possunt transmitti aut a viro aut a muliere, iubemus praeter illas causas nullo modo repudia fieri, aut per consensum nuptias solvi et concendere invicem delictis.

${ }^{51}$ Nov. 22,18: ... Si quid autem tale fiat et [...] aut etiam ipse rationabilem causam praestet ut mulier separetur ab eius matrimonio, quartam partem propriae substantiae cogatur exsolvere ei. Et usque ad quadringentas quidem auri libras substantiam habens centum libris damnificabitur, hoc est quarta substantiae parte, minorem autem ad hoc in quantum quartae facit quantitas. Si vero etiam maiorem praedictae quadringentarum auri librarum quantitatis substantiam habeat, non amplius centum auri damnificetur libris. Ad maximam namque plerumque respicientes dotem legem hanc scripsimus, substantiam illam merito secundum nostras leges aestimantes esse quae pura debitis videatur... 
zna tytułem kary był obowiązany dać pokrzywdzonej kobiecie jedną czwartą swojego majątku, jeżeli ta udowodniła, że uchodziła za jego żonę, wierząc w złożoną przysięgę ${ }^{52}$. Zastanawia fakt, że w Nov. 74,5 pr. mowa jest jedynie o zatrzymaniu jednej czwartej części majątku mężczyzny, nie ma natomiast klauzuli ograniczającej wielkość kary do stu funtów złota w przypadku, gdy majątek mniemanego męża przekraczał wartość czterystu funtów.

Ponadto Justynian nakazał uznać potomstwo pochodzące $\mathrm{z}$ tego rodzaju związku za legalne, nawet wbrew woli ojca, argumentując że zarówno ten, który zawarł małżeństwo, jak i ten, który począł dzieci z zamiarem uczynienia kobiety matką jego legalnych dzieci ${ }^{53}$, nie może odrzucić dzieci urodzonych z takich związków, traktując je jako dzieci nieprawego łoża, czyli naturalne ${ }^{54}$. Dzieci pochodzące $\mathrm{z}$ tego faktycznego związku należało traktować za dzieci prawego łoża także wówczas, gdy ich ojciec spłodził potomstwo w później zawartym małżeństwie po śmierci lub oddaleniu kobiety uchodzącej za jego żonę ${ }^{55}$.

W Nov. 117 Justynian utrzymał w mocy główną zasadę odpowiedzialności karnej za dostarczenie usprawiedliwionego powodu do jednostronnego rozwiązania małżeństwa, to jest że darowizna ante nuptias i posag przypadały na własność niewinnemu małżonkowi, chyba że z małżeństwa były wspólne dzieci. Wówczas zatrzymane przez niewinną żonę darowizny ante nuptias lub posag przez niewinnego męża były im oddawane jedynie w używanie i stanowiły własność dzieci ${ }^{56}$.

Jednakże cudzołożna żona w przypadku braku dzieci musiała ponadto oddać mężowi na własność ze swojego majątku pozaposagowego (bona paraphernales) równowartość jednej trzeciej wniesionego posagu. W przypadku posiadania wspólnych dzieci zarówno posag, jak i cały jej majątek parafernalny był zastrzeżony dla wspólnego potomstwa ${ }^{57}$.

52 Nov. 74,5 pr.: ... Sed si eam inrationabiliter expellat de domo, hoc ipsum sit adversus virum iusta causatio, et mulier hoc facto repudium ei mittat et exigat quartam, si uxor ostensa fuerit extitisse, licet extra dotem convenerit iuriiurando credens ...

${ }^{53}$ W końcowej części Nov. 74,5,1 Justynian podkreślił, że podstawą legitymacji potomstwa spłodzonego extra matrimonium są nuptiae wobec Boga zawarte $\mathrm{w}$ drodze przysięgi trwania w przyszłości w legalnym związku małżeńskim złożonej przez mężczyznę przy jednoczesnej zgodzie kobiety (... nisi eis etiam illi priores fuerint copulati, quorum similiter pater est, teste existente nuptiarum priorum quidem deo, secundarum autem lege ...).

${ }^{54}$ Nov. 74,5,1: Sit autem et soboles legitima etiam invito patre. Qui enim ad hoc nuptias fecit et filios procreavit, ut mulier legitimorum ei filiorum fieret mater, non potest ex tali natos germine rursus ut naturales abicere...

${ }^{55}$ Nov. 74,5,1: ... neque quasdam postea forte nuptias post mortem uxoris aut repudium contrahens eos qui ex illis nascuntur nuptiis velle [habere] solos esse legitimos ...

${ }^{56}$ Nov. 117,8 pr.; Nov. 117,9 pr.

${ }^{57}$ Nov. 117,8,2. Według tej noweli podobnym karom podlegał żonaty wspólnik w cudzołóstwie. Także jego żona tytułem kary otrzymywała posag i darowizny z okazji małżeństwa, a jeżeli miała z cudzołożnikiem dzieci, mogła jedynie pobierać pożytki z darowizn, ponieważ zgodnie z prawem własność na nich przysługiwała dzieciom. Co więcej, pozostały majątek, który znajdował się w rękach cudzołożnego ojca, stawał się własnością dzieci. Gdy zaś nie było dzieci, żona cudzołożni- 
Gdy repudium dokonała żona z powodu bezpodstawnego oskarżenia jej przez męża o cudzołóstwo ${ }^{58}$ albo z powodu jego rozwiązłości ${ }^{59}$, dodatkową karę dla męża stanowiło przekazanie byłej żonie ze swojego majątku kwoty równej jednej trzeciej wartości darowizny ante nuptias. Jednakże, gdy z rozwiązanego małżeństwa były dzieci, cały majątek ich ojca przechodził w ręce matki, która miała go zachować na własność dla dzieci.

W Nov. 117,7 Justynian postanowił, by dzieci pochodzące z rozwiązanego małżeństwa były dopuszczone do dziedziczenia po swoich rodzicach i utrzymywane z majątku ich ojca. Jednakże jeżeli ojciec dał powód do repudium $^{60}$, a matka nie zawarła powtórnego małżeństwa, dzieci miały pozostać przy niej ${ }^{61}$. Jeżeli natomiast matka dała powód do rozwiązania małżeństwa, dzieci pozostawały przy ojcu. Gdy zaś ojciec nie był w stanie poradzić sobie $\mathrm{z}$ utrzymaniem i wychowaniem dzieci (patrem quidem minus idoneum esse), a matka nie budziła zastrzeżeń ${ }^{62}$ (matrem vero locupletem), miała zatrzymać dzieci i je żywić ${ }^{63}$.

1.2. Rozwiązanie małżeństwa $\mathrm{w}$ drodze repudium bona gratia nie pociągało za sobą sankcji karnych dla żadnej ze stron. Niemniej skutkowało zwrotem posagu byłej żonie i zatrzymaniem darowizny ante nuptias przez męża ${ }^{64}$. Zasada ta odnosiła się także do przypadku repudium z powodu wstąpienia do klasztoru, chociaż Justynian w Nov. 22,5 pominął ją milczeniem. Wynika to z natury tego przypadku repudium, jak i z faktu braku uchylenia wcześniejszej regulacji dokonanej w tym zakresie w C. 1,3,52,15. Osoba, która zdaniem Justyniana wybrała lepszą drogę życia (ad meliorem migrans viam), dodatkowo

ka otrzymywała na własność darowiznę ante nuptias, cały zaś pozostały majątek męża, zgodnie z przepisami dawnego prawa przypadał fiskusowi.

${ }^{58}$ Nov. $117,9,4$.

${ }^{59}$ Nov. $117,9,5$.

${ }^{60} \mathrm{~W}$ tekście Nov. 117,7 nie został wprawdzie użyty termin repudium, lecz z faktu, iż jest tam mowa o powodach rozwiązania małżeństwa wynika, że tekst ten nie dotyczył rozwodu w sensie ścisłym, gdyż w jego przypadku dochodziło do rozwiązania małżeństwa za zgodnym porozumieniem stron.

${ }^{61} \mathrm{Na}$ lepszą zdatność matki do wychowania swoich dzieci, o ile nie wyszła ponownie za mąż, Justynian wskazał wcześniej w Nov. 22,38: mater fide dignior ad filiorum educationem videbatur [...] nisi ad secundas accesserit nuptias.

${ }^{62}$ To znaczy była zamożna i wiarygodna.

${ }^{63}$ Por. D. 43,30,1,3; 43,30,3,5; C. 5,49,1. Zgodnie z dyspozycją Nov. 117,7 obowiązek alimentacji działał w dwie strony, to znaczy, że nie tylko bogate dzieci miały alimentować ubogie matki, lecz także bogate matki miały alimentować ubogie dzieci. Co więcej, obowiązek ten obejmował wszystkich ascendentów i descendentów obojga płci (... Quemadmodum enim filii locupletes coguntur matrem egentem alere, ita instant decernimus et a matre locuplete filios pasci. Quod autem de alenda matre et filiis definivimus indigentibus, hoc quoque in omnibus ascendentibus descendentibusque personis utriusque naturae valere praecipimus).

${ }^{64}$ Nov. 22,6: ... Et hic siquidem dos, si qua est omnino data dos, sequitur mulierem, et reddit hanc vir, si eam contigit accipi, propter nuptias autem seu ante nuptias donatio manet apud virum nihil de suo damnificandum ...; Nov. 22,14: ... et non damnificabitur quidem dote, non tamen antenuptialem donationem lucrabitur ... 
została zobligowana w Nov. 22,5 do okazania jakiegoś niewielkiego zadośćuczynienia (quodam brevi dimisso solacio ei qui relinquitur) małżonkowi, którego opuściła. W tym też przypadku opuszczony małżonek otrzymywał także prawo do wszelkich korzyści wynikające z małżeńskich umów mortis causa z chwilą, gdy jego współmałżonek złożył profesję zakonną, jako że jej złożenie oznaczało śmierć dla świata.

Analogicznie została uregulowana w Nov. 22 kwestia majątkowych skutków prawnych zachodzących w przypadkach rozwiązania małżeństwa bona gratia $\mathrm{z}$ mocy samego prawa ${ }^{65}$.

W Nov. 117,12 Justynian podtrzymał wydane wcześniej dyspozycje prawa dotyczące skutków rozwiązania małżeństwa bona gratia ${ }^{66}$.

1.3. Za dokonanie repudium bez słusznej przyczyny małżonkowi, który się na to zdecydował, według Nov. 22,15 groziły sankcje karne takie same jak przewidziane względem małżonka, który dostarczył powodu do dokonania repudium propter iustam causam, czyli utrata posagu i darowizny przedmałżeńskiej ${ }^{67}$.

Od ogólnej zasady, że sprawca repudium sine causa tracił posag i darowizny przedmałżeńskie, wyjątek zachodził w razie repudium dokonanego przez małoletnich bez zgody rodziców. W tym przypadku rodzicom nie groziły żadne majątkowe sankcje karne ${ }^{68}$, posag i darowizny przedmałżeńskie należały się tym, którzy je ustanowili. Chociaż Justynian nie rozważył w tej noweli przypadku repudium sine causa małoletnich za zgodą rodziców, można sądzić, że gdyby do niego doszło, wówczas należałoby zastosować zasadę ogólną.

W Noweli 117 Justynian zaostrzył sankcje karne za dokonanie repudium sine causa. Według Nov. 117,13 kobietę, która dokonała repudium bez słusznej przyczyny, zamykano za karę na całe życie w klasztorze wskazanym przez biskupa miejsca zamieszkania małżonków. Musiała ona oddać swój posag mężowi, który winien był go zachować dla wspólnych dzieci. Gdyby zaś z małżeństwa nie mieli wspólnych dzieci, mąż otrzymywał go na własność. Traciła także wszelki inny swój majątek w dwóch trzecich na rzecz wspólnych dzieci, a w jednej trzeciej na rzecz klasztoru. Jeżeli zaś nie miała dzieci, dwie trzecie

${ }^{65}$ Nov. 22,7; 22,9; 22,10.

${ }^{66}$ Nov. 117,12: ... in his enim tribus casibus quae de eis prioribus nostris legibus continentur firma esse sancimus ...

${ }^{67}$ Wynika to z treści Nov. 22,15,3 (Si vero altera harum persona irrationabiliter repudium miserit, et hoc ipsum solvendi matrimonium sine ratione, subdita erit dudum a nobis dictis poenis...) rozpatrywanej w kontekście Nov. 22,15 pr. (Ceterae vero causam quaerunt inspicere aut a viro aut ab uxore factam, ut damnificent temerarium in casu horum quae ab eo data sunt, dotis dicimus aut propter nuptias donationis ...).

${ }^{68}$ Nov. 22,19: ... expectamus patrum consensum, ita neque transigere matrimonia sinimus in parentum laesionem circa illorum voluntatem. Sed etsi mittatur repudium, competere contra eos exactionem poenarum non sinimus, sive ipsi dederunt haec vel susceperunt, sive etiam cum aliis susceperunt ... 
przechodziły na klasztor, a jedna trzecia na ascendentów, a gdy nie miała ani dzieci, ani ascendentów, cały jej majątek przechodził na klasztor.

Jeżeli natomiast repudium bez słusznej przyczyny dokonał mężczyzna, musiał za karę zwrócić żonie posag wraz z darowizną przedmałżeńską. $Z$ własnego natomiast majątku tracił tyle, ile wynosiła trzecia część darowizny przedmałżeńskiej, którą był zobowiązany przekazać żonie na własność, chyba że mieli wspólne dzieci. W takim przypadku dostawała ona ten majątek tylko w użytkowanie z obowiązkiem zachowania go dla dzieci.

Jeżeli mężczyzna dokonał repudium sine causa w małżeństwie zawartym bez ustanowienia posagu, według Nov. 22,18, tak jak w przypadku repudium propter iustam causam z winy męża, musiał oddać byłej żonie jedną czwartą wartości swojego majątku po odliczeniu długów, o ile jego wartość nie przekraczała czterystu funtów złota. Gdy zaś przekraczała tę sumę, należało jej wypłacić sto funtów złota ${ }^{69}$. W świetle noweli 74,5 pr. kobieta w takim przypadku otrzymywała zawsze czwartą część majątku męża.

Przepisy dotyczące tego przypadku Justynian zmienił w Nov. 117,5 w ten sposób, że uzależnił wielkość części majątku męża przypadającego oddalonej sine causa żonie od liczby jego dzieci (bądź wspólnych, bądź z innego małżeństwa). Kiedy mąż miał nie więcej niż troje dzieci ${ }^{70}$, przysługiwała jej czwarta część jego majątku, a jeżeli miał więcej, miała prawo do części przysługującej każdemu z dzieci, przy czym otrzymywała ten majątek jedynie w użytkowanie, gdyż własność tych dóbr Justynian nakazał zachować dla dzieci. Gdy zaś nie miał z nią żadnych dzieci, otrzymywała własność nad należną jej częścią majątku męża ${ }^{71}$.

W Nov. 127,4 Justynian, wychodząc z założenia, że każdy, kto dokonuje repudium sine causa, dopuszcza się takiego samego przestępstwa, przyjął zasadę, że powinien podlegać bez względu na płeć takim samym sankcjom karnym ${ }^{72}$.

${ }^{69}$ Nov. 22,18: ... aut sine causa eam abiciat domo [...] quartam partem propriae substantiae cogatur exsolvere ei. Et usque ad quadringentas quidem auri libras substantiam habens centum libris damnificabitur, hoc est quarta substantiae parte, minorem autem ad hoc in quantum quartae facit quantitas. Si vero etiam maiorem praedictae quadringentarum auri librarum quantitatis substantiam habeat, non amplius centum auri damnificetur libris. Ad maximam namque plerumque respicientes dotem legem hanc scripsimus, substantiam illam merito secundum nostras leges aestimantes esse quae pura debitis videatur ...

${ }^{70}$ Nov. 117,5: ... si quidem usque tres habuerit filios eius vir sive ex ea sive ex alio matrimonio ... H. Insadowski uważa, że w Nov. 117,5 chodzi o przypadek ,kiedy ma ona troje dzieci”. Tymczasem w tekście Nov. 117,5 chodzi o dzieci męża i nie w liczbie trojga, ale do trojga; zob. H. Insadowski, s. 297.

${ }^{71}$ Nov. 117,5: ... si quidem usque tres habuerit filios eius vir sive ex ea sive ex alio matrimonio, quartam partem ex substantia viri accipere. Si autem amplius fuerint filii, tantum in utroque similiter casu accipere iubemus mulierem quantum uni competit filiorum: ita quippe ut usum solum in talibus rebus mulier habeat, dominium autem illis filiis servetur quos ex ipsis nuptiis habuit ...

72 Nov. 127,4: ... nullam esse differentiam quantum ad poenas inter virum et mulierem hoc praesumentes, sed iisdem poenis quae contra mulieres a nobis definitae sunt, si sine causa no- 
Zgodnie z tą zasadą postanowił w Nov. 134,11, że nie tylko kobieta, lecz również mężczyzna ma być dożywotnio relegowany do klasztoru za dokonanie repudium sine causa ${ }^{73}$. Małżonek, który odważył się go dokonać, był obowiązany przekazać potomstwu z tego lub poprzedniego małżeństwa cały swój majątek, uszczuplony o jedną trzecią na rzecz klasztoru, w którym przebywal $^{74}$. Ojciec nie mógł pobierać pożytków z dóbr przekazanych potomstwu ${ }^{75}$. Jeżeli zaś małżonkowie nie mieli potomstwa, małżonek skazany za karę na przebywanie w klasztorze, miał obowiązek przekazać trzecią część własnego majątku swoim ascendentom, o ile nie przyczynili się do dokonania repudium. Natomiast, gdy relegowany do klasztoru nie miał ani descendentów, ani ascendentów, albo ascendenci zaaprobowali jego repudium, cały majątek przypadał klasztorowi ${ }^{76}$.

W razie, gdyby małżonek, który dokonał repudium sine causa, jeszcze przed umieszczeniem $\mathrm{w}$ klasztorze zechciał pojednać się $\mathrm{z}$ opuszczonym współmałżonkiem, należało go traktować tak, jakby nie popełnił przestępstwa i uwolnić od wszelkich kar ${ }^{77}$. Gdyby jednak nie doszło do ponownego nawiązania wspólnoty życia z drugim małżonkiem na skutek jego sprzeciwu, spadały na niego wszystkie kary przewidziane za dokonanie repudium sine causa $^{78}$.

strae legi cognita matrimonia distrahunt, etiam viros subdi hoc praesumentes, et similes esse poenas in viro et muliere. In delicto enim aequali proximas eis imminere poenas iustum putavimus esse.

${ }^{73}$ Nov. 134,11,1: ... et tam virum quam mulierem in monasterium mitti in omnibus vitae suae temporibus ...; według Nov. 134,11,2 w razie niezgodnego z prawem rozwiązania małżeństwa, czy to $\mathrm{w}$ drodze sporządzenia libellum repudii, czy instrumentum divortii, urzędników, którzy dokonali pisemnego sporządzenia tego rodzaju aktów na wniosek osób zainteresowanych, poddawano karom cielesnym i wypędzano (in exilium destinari).

${ }^{74}$ Nov. 134,11,1: ... iubemus, si quidem descendentes habuerint sive ex ipso sive ex alio matrimonio, substantiam eorum illis dari secundum legem ordinem [...] et de singulorum facultatibus quaternas uncias monasteriis in quibus mittuntur separari ...

${ }^{75}$ Nov. 134,11,1: ... viro nihilo minus neque usum habente datae partis filiis ...

${ }^{76}$ Nov. 134,11,1: ... Si vero descendentes non habeant, sed ascendentes inveniantur, tertiam partem substantiae accipere eos, si non iniquitati solutionis matrimonii consenserint, duas vero partes monasteriis in quibus unusquisque mittitur separari. Si vero neque descendentes neque ascendentes inveniantur, vel ascendentes consenserunt facto, iubemus omnem substantiam monasteriis in quibus missi sunt dari ...

77 Nov. 134,11,3: Si vero hi qui matrimonium solvere praesumpserunt voluerint iterum sibi coniungi prius quam mittantur in monasterio, licentiam eis damus hoc facere et praedictas poenas concedimus eis et proprias habere substantias et ita ad invicem vivere, tamquam si nihil delictum fuisset ...

${ }^{78}$ Nov. 134,11,3: ... Uno vero volente matrimonium revocare, si non consentiat alia persona, contra eum qui noluerit teneant poenae. Kto zaś z urzędników odpowiedzialnych za przestrzeganie niniejszej konstytucji zaniechałby karania tego rodzaju przestępstw i nie przestrzegał jej wszystkich postanowień, podlegał wygnaniu i konfiskacie majątku. Biskupi miejsca mieli zaś zadbać, aby powierzone ich opiece osoby udały się do klasztorów i dopilnować windykacji dóbr należnych klasztorom (Nov. 134,11,4). 
2. Ograniczenia dotyczące zawierania powtórnego małżeństwa

W myśl Nov. 22 jeżeli jednostronne rozwiązanie małżeństwa nastąpiło $\mathrm{z}$ winy męża ${ }^{79}$ lub mąż oddalił żonę sine causa ${ }^{80}$ albo nastąpiło rozwiązanie małżeństwa bona gratia ${ }^{81}$ kobieta była zobowiązana do powstrzymania się od ponownego małżeństwa przez okres roku. $\mathrm{W}$ tych przypadkach nałożony na kobietę obowiązek abstynencji nie stanowił dla niej kary, lecz był podyktowany obawą zmieszania krwi ${ }^{82}$, czyli potrzebą zachowania tempus lugendi.

Jeżeli natomiast kobieta oddaliła swojego męża $\mathrm{z}$ własnej winy ${ }^{83}$ albo sine iusta causa ${ }^{84}$, albo on ją oddalił propter iustam causam, wówczas za karę przez pięć lat wiązał ją zakaz ponownego zamążpójścia ${ }^{85}$. Nowe małżeństwo takiej kobiety, zawarte przed upływem pięciu lat, Justynian nakazał traktować za niegodziwe i bezprawne oraz pozwolił każdemu je zaskarżyć ${ }^{86}$.

Wydaje się, że w przypadku repudium propter iustam causam dokonanego przez żonę z powodu nieudowodnionego jej cudzołóstwa, w świetle Nov. 117,9,4 mężczyznę wiązał ten sam zakaz powtórnego małżeństwa, który ciążył na żonie, jeżeli zostało jej udowodnione adulterium. Wynika to jednoznacznie ze słów ita tamen ut etiam propter illatam adulterii accusationem et non probatam illis quoque maritus subdatur suppliciis, quae esset passu mulier, si huiusmodi fuisset accusatio comprobata.

Jednak w przypadku dokonania repudium sine iusta causa od Nov. 117,13 kobieta z racji przymusowego dożywotniego umieszczenia w klasztorze była całkowicie pozbawiona możliwości zawarcia powtórnego małżeństwa. Tej samej sankcji osobistej od Nov. 127,4 podlegał również mężczyzna w razie dokonania tego rodzaju repudium, co potwierdza expressis verbis Nov. 134,11 .

${ }^{79}$ Nov. 22,18: ... sin vero per culpam mariti $[. .$.$] hic annum custodiat propter seminis confu-$ sionem ...

${ }^{80}$ Nov. 22,16 pr.: Si vero etiam rationabiliter mulier repudium miserit et in certaminibus vicerit, aut vir irrationabiliter eam abiciens subiacuerit poenis, lucretur quidem lucra primitus dicta, erubescat autem ante annum completum ad secunda vota venire ...

${ }^{81}$ Nov. 22,16 pr.: ... tanta est prohibitio ex hoc, quia, licet bona gratia dissolvi contingat matrimonium, tamen etiam sic ex Anastasii piae memoriae constitutione in annum prohibitio secundarum nuptiarum mulieribus instituta est; Nov. 22,18: ... aut etiam bona gratia distrahitur, merito et hic annum custodiat propter seminis confusionem ...

${ }^{82}$ Nov. 22,16 pr.: ... sobolis confusionem rationabilis est suspicio ...; Nov. 22,18: ... annum custodiat propter seminis confusionem ...

${ }^{83}$ Nov. 22,18: ... et si mulier per culpam priopriam separetur a viro indotata existens ...

${ }^{84}$ Nov. 22,15,3: ... Insuper etiam uxor rea omnino ex memoratis causis pro irrationabilis repudii missione facta et in quinquennium totum ad secundum venire prohibetur matrimonium ...; Nov. 22,18: ... aut etiam mittat ei sine aliqua causa rationabili repudium [...] quinqennium observandum mulieri est, et secundis non copulabitur nuptiis ...

${ }^{85}$ B. Biondi skomentował ten zakaz jako ciężką sankcję osobistą; zob. B. Biondi, Il diritto romano cristiano..., s. 181.

${ }^{86}$ Nov. 22,15,3: ... et ante quinqennium nuptias non esse sine reactu neque legitimas vocari, sed omnis volens adeat et accuset fatum tamquam contra legem praesumptum. 
Przeprowadzona analiza nowel Justyniana pod kątem zawartych w nich regulacji dotyczących repudium pozwala stwierdzić, że punkt wyjścia reformy Justyniana w tym zakresie stanowily przepisy Nov. 22. Stanowi ona swoisty kodeks przepisów dotyczących rozwiązywania małżeństw, w tym odnoszących się do repudium. W kolejnych jej rozdziałach cesarz opisał znane już z Kodeksu dopuszczalne przypadki repudium bona gratia oraz skatalogował przyczyny repudium propter iustam causam.

Do zasadniczej redukcji przyczyn repudium doszło dopiero w Nov. 117, objęła ona zarówno repudium propter iustam causam, jak i repudium bona gratia. Derogacja stanowionego wcześniej w tym zakresie prawa dowodzi, że Justynian pozostawał niewątpliwie pod coraz większym wpływem Kościoła katolickiego, który opowiadał się za nierozerwalnością małżeństwa.

W kolejnych nowelach Justynian zaostrzał sankcje karne za bezprawne oddalenie współmałżonka. Ostatecznie w Nov. 127 doprowadził do ujednolicenia karania mężczyzn i kobiet za dokonanie repudium sine causa.

Reasumując, należy stwierdzić, że ograniczenia repudiów wprowadzone przez Justyniana w nowelach były daleko idące, czym cesarz ten w istotny sposób ograniczył zasadę wolności w sprawach małżeńskich i świadomie przyczynił się do umocnienia doktryny Kościoła katolickiego o nierozerwalności małżeństwa. Jednak nawet on całkowicie nie zakazał dokonywania repudiów.

\section{REPUDIUM AND ITS LEGAL EFFECTS IN JUSTINIAN'S NOVELS}

\section{Summary}

In his Novels, Justinian strongly limited the legal possibilities of unilaterally sending a spouse away, by which he significantly restricted the principle of freedom in marital causes and consciously contributed to the consolidation of the Catholic Church's doctrine of indissolubility of marriage. Nevertheless, even he did not completely ban repudium.

The point of departure of Justinian's reform in this respect was Nov. 22 - a collection of provisions on the dissolution of marriage, including those on repudium. Its causes were radically restricted only by Nov. 117, which covered both repudium propter iustam causam and repudium bona gratia. In successive novels, Justinian increased penalties for unlawfully sending a spouse away. Finally, in Nov. 127, he introduced uniform penalties for men and women for committing repudium sine causa. 


\section{REPUDIUM ET SES EFFETS JURIDIQUES DANS \\ LES NOVELLES DE JUSTINIEN}

\section{Résumé}

Dans ses Novelles, Justinien limite considérablement les possibilités légales de répudier unilatéralement le conjoint, par quoi il limitera de manière significative la règle d'indépendance dans les affaires matrimoniales. Ainsi, il contribue consciemment au renforcement de la doctrine de l'Église catholique sur l'indissolubilité du mariage. Toutefois, même Justinien n'a pas interdit totalement de procéder à la repudium. Le point de départ de la réforme de Justinien en la matière constitue le règlement de la Nov. 22. C'est une sorte de code des dispositions relatives à la dissolution des mariages, dont celles qui concernent repudium. Une réduction principale des motifs de repudium est réalisée seulement dans la $117^{e}$ Novelle qui traite tant de repudium propter iustam causam que de repudium bona gratia. Dans les Novelles suivantes, Justinien aggrave les sanctions pénales prononçables suite à une répudiation illégitime du conjoint. Finalement, la $127^{e}$ Novelle conduit à l'uniformisation des sanctions applicables aux hommes et aux femmes pour une repudium sine causa. 